\title{
PEMBANGUNAN EKONOMI DAN LINGKUNGAN BERKELANJUTAN BERBASIS REFORMA AGRARIA DI BEBERAPA NEGARA \\ DAN INDONESIA KEKINIAN
}

\section{Virtuous Setyaka}

\begin{abstract}
This paper intends to discuss the theoretical discourse and practice of Agrarian Reform in various countries of the world. By exploring the concepts and theories of Agrarian Reform, Economic Development and Sustainable Environment and practices in various countries through literature studies, it is expected to contribute as an elaboration which may be important as a comparison in the implementation of sustainable development in Indonesia especially in the implementation of Agrarian Reform for economic welfare, Environmental sustainability, and minimization of social conflict of kekininian.
\end{abstract}

Keyword: Economic Development, Sustainable Environment, Agrarian Reform.

\section{Pendahuluan}

Gunnar Myrdal, seorang ekonom dan pemenang Nobel, pernah mengatakan bahwa di sektor pertanianlah pertempuran untuk pembangunan ekonomi jangka panjang akan dimenangkan atau akan mengalami kekalahan ${ }^{1}$. Mencermati pernyataan Myrdal tersebut, ada beberapa poin penting yang perlu dicatat dan dipahami lebih serius sebagai frasa kunci, yakni: pembangunan sektor pertanian dan pembangunan ekonomi jangka panjang. Pembangunan ekonomi di dalam sektor pertanian yang akan berpengaruh dalam pembangunan ekonomi secara keseluruhan

\footnotetext{
${ }^{1}$ Jawied Nawabi (2015), Land Reform: A Precondition for Sustainable Economic Development, diakses dari http://www.dollarsandsense.org/archives/2015/051 5nawabi.html.
}

di sebuah negara, secara mendasar dikenali dengan Reforma Agraria (RA).

Rogers (2010) menyatakan bahwa RA adalah sebuah hal yang fundamental untuk mengatasi krisis pangan, namun tidak menerima perhatian yang layak. Dalam tatanan dunia yang ditujukan untuk pasar bebas kapitalisme spekulatif, RA bukanlah prioritas bagi pemerintah di Negara Berkembang. Sebaliknya, mereka lebih peduli dengan mengatasi krisis energi dengan mengalokasikan tanah diolah untuk produksi agrofuel (misalnya di Brazil) yang dengan hal itu memperdalam krisis pangan. Selain itu, ekspansi besar-besaran produksi agrofuel telah mendorong pembatasan kepemilikan tanah dan menghasilkan ketergantungan yang tumbuh pada ekonomi sosial monokultur 
dan merusak lingkungan. Diversifikasi pertanian monokultur menyebabkan degradasi lingkungan dan menciptakan lapangan kerja yang bergaji rendah ${ }^{2}$. Sebaliknya, RA diyakini tidak hanya mempengaruhi pembangunan ekonomi secara parsial, namun secara komperehensif juga mempengaruhi pada kelestarian lingkungan, juga mampu mempengaruhi dalam meminimalisasi konflik sosial. Ketiga prisip tersebut yakni kesejahteraan ekonomi, kelestarian lingkungan, dan konflik sosial minimal (yang mengarah pada keadilan sosial) tersebut kemudian dikenal sebagai pembangunan yang berkelanjutan.

Wacana teoritik dan praktik tentang RA dan turunannya telah mendunia, atau menjadi isu global yang harus terus menjadi salah satu perhatian di Indonesia. Salah satu bukti empirisnya adalah ketika FAO juga mengundang Indonesia ke Konferensi "Reformasi Agraria dan Pembangunan Desa” di Roma, bulan Juli 1979 yang dihadiri oleh banyak Kepala Negara di dunia dan dipenuhi oleh Indonesia sebagai salah satu anggota FAO. Delegasi besar Indonesia dipimpin oleh Menteri Pertanian saat itu dan disertai oleh

\footnotetext{
${ }^{2}$ Wilder Robles dan Henry Veltmeyer (2015), The Politics of Agrarian Reform in Brazil: the Landless Rural Workers Movement, New York: Palgrave Macmillan, h. 3.
}

sejumlah penasehat dan para Dosen Indonesia ${ }^{3}$.

Tulisan ini bermaksud untuk mendiskusikan tentang wacana teoritik dan praktik RA di berbagai negara di dunia sebagai sebuah elaborasi yang mungkin penting sebagai perbandingan dalam penyelenggaraan pembangunan berkelanjutan di Indonesia khususnya dalam pelaksanaan RA untuk kesejahteraan ekonomi, kelestarian lingkungan, dan minimalisasi konflik sosial.

\section{Reforma Agraria dan Pembangunan Berkelanjutan}

RA mencakup perbaikan dalam penguasaan lahan dan dalam organisasi pertanian $^{4}$, atau secara legal formal (di Indonesia) disebut juga dengan Pembaruan Agraria adalah proses restrukturisasi (penataan ulang susunan) kepemilikan, penguasaan, dan penggunaan sumbersumber agraria (khususnya tanah) ${ }^{5}$. RA dapat diartikan sebagai suatu upaya

\footnotetext{
${ }^{3}$ Sajogyo, "Pengantar” dalam Gunawan Wiradi (2000), Reforma Agraria: Perjalanan yang Belum Berakhir, diterbitkan pertama kali oleh: Insist Press, KPA dan Pustaka Pelajar, September 2000, Edisi Revisi: September 2009, Bogor, Bandung, dan Jakarta: Sajogyo Institute, Akatiga, dan Konsorsium Pembaruan Agraria (KPA), h. v. ${ }^{4}$ Prem Nath (1999), The FAO Field Programme and Agricultural Development in Asia and The Pacific, RAP Publication 1999/28, Food and Agriculture Organization of the United Nations Regional Office for Asia and the Pacific December 1999.

${ }^{5}$ BPN RI, Sekilas Reforma Agraria, diakses dari http://www.bpn.go.id/Program/Reforma-Agraria.
} 
sistematik, terencana, dan dilakukan secara relatif cepat, dalam jangka waktu tertentu dan terbatas, untuk menciptakan kesejahteraan dan keadilan sosial serta menjadi pembuka jalan bagi pembentukan masyarakat 'baru' yang demokratis dan berkeadilan; yang dimulai dengan langkah menata ulang penguasaan, penggunaan, dan pemanfaatan tanah dan kekayaan alam lainnya, kemudian disusul dengan sejumlah program pendukung lain untuk meningkatkan produktivitas petani khususnya dan perekonomian rakyat pada umumnya ${ }^{6}$.

Kekhususan pada tanah ini seringkali juga disebut secara populer dengan Land Reform (LR) atau reforma(si) tanah/lahan di seluruh dunia. Dalam tulisan Bachriadi (2007), inti dari RA adalah LR dalam pengertian redistribusi pemilikan dan penguasaan tanah. Meskipun demikian LR tidak akan berhasil jika tidak didukung oleh program-program penunjang seperti pengairan, perkreditan, penyuluhan, pendidikan, pemasaran, dan sebagainya. Tuma (1965) menyimpulkan bahwa LR

\footnotetext{
${ }^{6}$ Dianto Bachriadi (2007), Reforma Agraria untuk Indonesia: Pandangan Kritis tentang Program Pembaruan Agraria Nasional (PPAN) atau Redistribusi Tanah ala Pemerintahan SBY, Sebuah tulisan untuk bahan diskusi dalam Pertemuan Organisasi-organisasi Rakyat se-Jawa di Magelang, 6-7 Juni 2007. Tulisan yang sama pernah disampaikan dalam diskusi di Fakultas Hukum Universitas Bengkulu (UniB), Bengkulu, 2 Juni 2007, dan beberapa pertemuan/diskusi lainnya di Indonesia. Diakses dari http://ikuswahyono.lecture.ub.ac.id/files/2015/11/D BReforma-Agraria-untuk-Indonesia.pdf.
}

dalam pengertian luas akhirnya dapat disamakan dengan RA, yakni suatu upaya untuk mengubah struktur agraria demi terciptanya tujuan sebagaimana disebutkan di atas. Jadi RA dapat diartikan sebagai LR plus $^{7}$.

Konsep reformasi tanah yang diperluas dapat dipahami dengan sejarah kolonialisasi, misalnya bahwa seluruh proses pemukiman kolonial di Amerika Utara, Amerika Tengah dan Selatan, Australia, dan Selandia Baru adalah salah satu reformasi tanah besar-besaran, perampasan tanah masyarakat adat dan mendistribusikannya kepada para Pemukim Eropa pada saat itu. Reformasi tanah dapat dipahami sebagai pengalaman yang jauh lebih umum dari Dunia (yang dianggap) Maju daripada biasanya yang dianggap terdapat didalam berbagai literatur tentang ekonomi ${ }^{8}$.

Michael Lipton menteorisasikan dan mentaksonomikan praktik LR dengan mendefinisikannya sebagai perundangundangan (legislasi) yang diniatkan dan benar-benar diperuntukkan meredistribusi kepemilikan, (mewujudkan) klaim-klaim, atau hak-hak atas tanah pertanian, dan dijalankan untuk memberi manfaat pada kaum miskin dengan cara meningkatkan

\footnotetext{
${ }^{7}$ Ibid.

${ }^{8}$ Jawied Nawabi (2015), Land Reform: A Precondition for Sustainable Economic Development, diakses dari http://www.dollarsandsense.org/archives/2015/051 5nawabi.html.
} 
status, kekuasaan, dan pendapatan absolut maupun relatif mereka, berbanding dengan situasi tanpa perundang-undangan tersebut $^{9}$. Lebih dari itu, jika menginginkan resep kebijakan dalam pembangunan yang lebih menyeluruh, maka sangatlah mendesak bagi suatu pemerintahan negara untuk melampaui redistribusi tanah, yakni harus mendukung langkah-langkah pembangunan pedesaan lainnya seperti peningkatan kredit pertanian, koperasi untuk pasokan pertanian berupa masukan dan pemasaran, dan penyuluhan untuk memfasilitasi penggunaan tanah dialokasikan kembali lebih produktif ${ }^{10}$.

Dalam pembangunan di sektor pertanian secara umum, terdapat berbagai peluang dan kendala untuk meningkatkannya yaitu geografi, demografi, Sumber Daya Alam (SDA), ideologi, politik, ekonomi, sosial budaya, dan pertahanan keamanan. Sedangkan khusus di Indonesia, terdapat faktor-faktor lainnya yang berpengaruh pada pembangunan sektor pertanian, yakni permasalahan sosial-ekonomi dan

\footnotetext{
${ }^{9}$ Dalam Noer Fauzi Rachman (2012), Land Reform Dari Masa Ke Masa, Yogyakarta dan Bogor: Sekolah Tinggi Pertanahan Nasional dan Sajogyo Institute (SAINS), h. 1-2.

${ }^{10}$ Prem Nath (1999), The FAO Field Programme and Agricultural Development in Asia and The Pacific, RAP Publication 1999/28, Food and Agriculture Organization of the United Nations Regional Office for Asia and the Pacific December 1999.
}

pengembangan investasi yang diikuti penggunaan teknologi dalam proses produksi pertanian $^{11}$. Sedangkan RA atau setidaknya reformasi tanah lebih tepatnya realokasi hak untuk membangun distribusi lahan pertanian yang lebih adil, diyakini dapat menjadi strategi ampuh untuk mempromosikan baik pembangunan ekonomi jangka panjang, kualitas kelestarian lingkungan ${ }^{12}$, dan dengan demikian dapat minimalisasi konflik sosial.

\section{Reforma Agraria di Berbagai Negara}

Reformasi tanah dan kepemilikan untuk didayagunakan pada mulanya menjadi dominan dalam diskusi kebijakan di hampir semua negara khususnya di Asia. Antusiasme berkurang pada era 1950-an dan 1960-an meskipun upaya sporadis untuk mendistribusikan tanah terus dilakukan. Perbaikan penguasaan lahan dalam praktik sewa tanah lebih mudah diselenggarakan ketimbang redistribusi tanah, namun hal tersebut ternyata tidak membuat banyak kemajuan. Kurangnya kemauan politik dalam

\footnotetext{
${ }^{11}$ Guntur IC Lelono, Pembangunan Sektor Pertanian Dapat Meningkatkan Ketahahan Pangan Nasional, diakses dari http://fhukum.unpatti.ac.id/htn-han/169pembangunan-sektor-pertanian-dapatmeningkatkan-ketahahan-pangan-nasional. 12 James K. Boyce, Peter Rosset, dan Elizabeth A. Stanton (2005), Land Reform and Sustainable Development, Working Paper Series Number 98 June 2005, Political Economy Research Institute (PERI), University of Massachusetts Amherst.
} 
pelaksanaan dan struktur keseluruhan dari masyarakat nasional yang bias dengan mendukung kelompok kepentingan tertentu yang resisten terhadap perubahan menjadi alasan utama mengapa reformasi tanah sebagian besar Asia mengalami kegagalan. Pasca era 1970-an penekanan berpindah dari reformasi tanah menuju RA. Situasi yang berlaku sampai dengan akhir era 1980-an, akses ke tanah ditentukan dengan tren faktor ekonomi demografi, struktural dan lain dan oleh kebijakan pemerintah dalam praktiknya, sangat sedikit mengadopsi program yang signifikan untuk RA. Singkatnya, kegagalan reformasi tanah meliputi kurangnya komitmen pemerintah, kelemahan dalam desain perundangundangan, kegagalan menyediakan layanan dukungan diperlukan penerima manfaat, kurangnya organisasi lokal, keterbatasan anggaran, kekurangan personil, kurangnya kerjasama, dan sebagainya. Masalah ini sangat umum ditemukan di negara-negara Asia. Pelaksanaan reformasi tanah di sebagian besar negara masih akan memakan waktu bertahun-tahun untuk menyelesaikan, sehingga pajak tanah progresif harus diperkenalkan sedini mungkin $^{13}$. Lipton mengamati perdebatan

\footnotetext{
${ }^{13}$ Prem Nath(1999), The FAO Field Programme and Agricultural Development in Asia and The Pacific, RAP Publication 28, December 1999, Food and Agriculture Organization of the United Nations Regional Office for Asia and the Pacific.
}

tentang LR di berbagai Negara (yang disebut sedang) Berkembang sebagi isu yang sering kali menjadi isu panas dalam kurun waktu dua puluhan tahun pasca Perang Dingin yang berakhir pada 1990$\mathrm{an}^{14}$.

Dalam survei di atas kertas, strategi reformasi tanah diilustrasikan oleh reformasi pasca perang di Asia Timur dan LR dari bawah yang dipimpin oleh Gerakan Buruh Tak Bertanah (Movimento dos Trabalhadores Rurais Sem Terra/MST) di Brazil. LR dapat mengurangi kemiskinan di pedesaan tidak hanya dengan menyalurkan potongan yang lebih besar dari 'kue pembangunan' pertanian dalam pendapatan rumah tangga yang sebelumnya berpendapatan rendah, tetapi juga dengan meningkatkan ukuran 'kue pembangunan' dengan meningkatkan produktivitas lahan. Kontribusi reformasi tanah untuk pengurangan kemiskinan dapat diperbesar oleh efek melubernya ekonomi di perkotaan. Dengan kebijakan lingkungan yang mendukung, reformasi tanah juga dapat menumbuhkan transisi ke pertanian berkelanjutan, karena keuntungan komparatif lingkungan peternakan yang masih kecil ${ }^{15}$. Sementara

\footnotetext{
${ }^{14}$ Dalam Noer Fauzi Rachman (2012), Land Reform Dari Masa Ke Masa, Yogyakarta dan Bogor: Sekolah Tinggi Pertanahan Nasional dan Sajogyo Institute (SAINS), h. 1-2.

15 James K. Boyce, Peter Rosset, dan Elizabeth A. Stanton (2005), Land Reform and Sustainable Development, Working Paper Series Number 98
} 
itu dalam penelitian yang dilakukan oleh Flávia L. Leite, Marcellus M. Caldas, Cynthia Simmons, $\quad$ Stephen G. Perz, Stephen Aldrich, dan Robert T. Walker, yaitu membandingkan pemukiman Reformasi Tanah dalam Tindakan Langsung (Direct-Action Land Reform/DALR) di dua daerah yang berbeda dari Amazon timur: South Pará dan Transamazon, dinyatakan bahwa reforma agraria yang dipimpin negara (State-Led Agrarian Reform/SLAR) pada pemukiman yang didirikan di Amazon pada 1970-an menyebabkan degradasi lingkungan dan hasil sosial ekonomi campuran. Sedangkan DALR telah berkembang dan mengarah ke pembukaan hutan baru atas nama RA. Hasil analisis data survei rumah tangga menunjukkan bahwa pemukiman DALR di dua wilayah studi, berbeda secara substansial dalam hal sejarah mereka dari pembentukan dan konteks regional. Namun, hasil sosial dan lingkungan tidak selalu berbeda antara dua bidang studi, yang pada gilirannya DLAR hasilnya menyerupai $\operatorname{SLAR}^{16}$. Ada juga penelitian tentang MST sebagai gerakan akar rumput populer berperan dalam membawa kelestarian lingkungan. Tujuan

June 2005, Political Economy Research Institute (PERI), University of Massachusetts Amherst. ${ }^{16}$ Leite, F.L., Caldas, M.M., Simmons, C. et al (2011). The Social Viability and Environmental Sustainability of Direct Action Land Reform Settlements in the Amazon, Environ Dev Sustain, 13: 773. doi:10.1007/s10668-011-9289-5. utama $\quad$ MST sendiri adalah menghubungkan antara permintaan otonomi dan sentralitas hidup masyarakat dalam mewujudkan lingkungan yang berkelanjutan. Tanpa otonomi dan berpusat pada masyarakat tersebut, dengan perubahan dalam wacana dan praktik tentang kelestarian lingkungan, organisasiorganisasi lingkungan yang dilembagakan sebagai organisasi-organisasi nonpemerintah (Ornop) atau nongovernmental organizations (NGOs) mungkin berhasil dalam mengangkat isuisu lingkungan global, namun tidak efektif dalam mendapatkan hasil kecuali hanya berjangka pendek. Gerakan akar rumput seperti MST di Brazil memiliki motivasi yang diperlukan, tatanan sejarah dan geografi dengan fleksibilitas untuk melakukan tindakan langsung yang lebih sering dalam menekan para pengambil keputusan. MST adalah gerakan akar rumput yang sukses dan telah berhasil memperoleh dukungan global dalam mengambil inisiatif pembangunan lingkungan berkelanjutan ${ }^{17}$.

Pemerintah Negara Zimbabwe pada pergantian milenium baru mengambil langkah untuk memastikan bahwa pelaksanaan redistribusi tanah terjadi di

\footnotetext{
${ }^{17}$ Elif Gunduzyeli (2008), The MST: Land Reform and the Way to Environmental Sustainability, MSc. Environmental Social Sciences Dissertation at University of Kent School of Social Policy, Sociology and Social Research.
} 
semua tingkatan masyarakat. Kebijakan yang dijuluki dengan Fast Track Land Reform Program (FTLRP) sepertinya dilakukan pada tingkatan yang lebih cepat bahkan jika dibandingkan dengan apa yang telah disaksikan dalam berbagai tindakan untuk mencapai kemerdekaan negaranya. Kebijakan itu dilihat dari gerakan sejumlah rumah tangga yang menjadikan lahanlahan utama untuk diberdayakan termasuk di berbagai kawanan yang lahan-lahannya bahkan tidak pernah dibersihkan. Terlihat telah terjadi degradasi lingkungan yang meningkat khususnya melalui deforestasi untuk persiapan lahan pertanian dan juga pengumpulan kayu bakar akibat dari negara Zimbabwe yang masih menghadapi kekurangan daya atau sumber energi. Kegiatan tersebut akhirnya memiliki dampak yang negatif pada iklim. Reformasi tanah sebagai tulang punggung untuk pembangunan berkelanjutan di Zimbabwe tidak seharusnya berbalik menjadi penyebab perubahan iklim. Namun, para petani baru harus dididik tentang pentingnya melestarikan lingkungan untuk menghindari perubahan iklim yang merugikan ${ }^{18}$.

\footnotetext{
${ }^{18}$ Dorothy Goredema, Vongai NyawoShava dan Percyslage Chigora (2011), Land Reform, Climate Change and Sustainable Development in Zimbabwe, Pakistan Journal of Social Sciences, Year: 2011, Volume: 8, Issue: 3, Page No.: 146-151, DOI: 10.3923/pjssci.2011.146.151.
}

Di Afrika Selatan, meskipun terdapat kerangka kebijakan yang mendukung dan meningkatkan kesadaran lingkungan, namun semakin banyak bukti menunjukkan bahwa kelestarian lingkungan bukanlah pusat dari perencanaan dan pengambilan keputusan proses reformasi tanah. Peningkatan tekanan pada pemerintah untuk memenuhi target reformasi lahan, prosedur penilaian lingkungan yang rumit dan sering tidak pantas, dan banyaknya produk hukum yang membingungkan, akhirnya semua itu berkontribusi mengabaikan pertimbangan kelestarian lingkungan dalam jangka panjang dan dalam reformasi tanah. Hal ini diperburuk dengan pengakuan kelangkaan sumber daya, kurangnya rencana pengelolaan lingkungan proaktif dan preemptive, serta kapasitas pelaksanaan yang memadai. Seharusnya, penggabungan isu kelestarian lingkungan dalam penyediaan pemukiman dan reformasi tanah secara signifikan meningkatkan hasil lingkungan, sosial dan ekonomi dari proyek-proyek pembangunan yang dilakukan pemerintah. Kelestarian lingkungan mestinya juga dijamin dalam mencapai tujuan-tujuan pembangunan $^{19}$.

\footnotetext{
${ }^{19}$ R. P. Wynberg dan M. Sowman (2007), Environmental Sustainability and Land Reform in South Africa: A Neglected Dimension, Journal of Environmental Planning and Management, Volume 50, 2007, Issue 6, Pages 783-802.
} 
Untuk mempelajari evolusi kepemilikan dan penggunaan lahan atau tanah dan hubungannya dengan hasil pembangunan misalnya di Negara Panama. Reformasi tanah secara resmi dimulai tahun 1962, perubahan penting rezim kepemilikan dan hasil penggunaan lahan telah terkonsentrasi di lima belas tahun terakhir, bertepatan dengan perluasan ideologi neoliberal di wilayah tersebut. Kebijakan tanah baru-baru ini di Panama, diciptakan untuk mendorong pertumbuhan ekonomi yang didorong oleh investor asing dengan akses modal. Dengan demikian kebijakan pertanahan di negara tersebut adalah hasil dari warisan kepemilikan lahan pasca kolonial. Kebijakan pertanahan yang diimplementasikan adalah untuk merespon hasil pembangunan jangka pendek yang dipengaruhi oleh konteks ekonomi politik yang luas. Kebijakan penggunaan lahan dan berikutnya praktik penggunaan lahan sebagi hasil perubahan berdampak pada kehidupan masyarakat lokal yang ternyata tidak sama ${ }^{20}$.

\section{Reforma Agraria dan Pembangunan}

\section{Berkelanjutan di Indonesia Kekinian.}

Sejak kemerdekaan Republik Indonesia, salah satu permasalahan yang terus muncul selain pembangunan ekonomi

\footnotetext{
${ }^{20}$ Ana K. Spalding (2016), Exploring the Evolution of Land Tenure and Land Use Change in Panama: Linking Land Policy with Development Outcomes, Land Use Policy 61 (2017) 543-552.
}

secara umum yang belum menyejahterakan dan distibusi hasilnya yang adil dan merata adalah kegagalan kebijakan khususnya tentang pengelolaan sumber daya alam dan lingkungan hidup. Padahal kesadaran pemikiran tentang pembangunan ekonomi, pengelolaan sumber daya, dan lingkungan yang berkelanjutan dapat diawali dengan RA sudah menjadi wacana. Sehingga upaya-upaya mewujudkan itu semua terus diperjuangkan oleh berbagai pihak, bukan hanya pemerintah namun juga Ornopornop atau NGOs (di Indonesia dikenal dengan Lembaga Swadaya Masyarakat/LSM).

Salah satu pencapaian dalam upaya RA di Indonesia adalah ketika Sidang Tahunan MPR RI Tahun 2001 menghasilkan sebuah ketetapan tentang pengelolaan sumber daya alam dan lingkungan hidup yaitu disyahkannya TAP MPR RI No. IX/MPR-RI/2001 tentang Pembaruan Agraria dan Pengelolaan Sumberdaya Alam. Inisiasi dilakukan oleh Kelompok Kerja Ornop untuk Pembaruan Agraria dan Pengelolaan Sumberdaya Alam yang mengawal proses perumusan kebijakan ini sampai menjadi sebuah ketetapan MPR. Kelompok Kerja Ornop untuk Pembaruan Agraria dan PSDA menyatakan ada beberapa agenda penting 
harus dilaksanakan MPR agar ketetapan tersebut bermanfaat bagi masyarakat ${ }^{21}$ :

a. penyelesaian konflik dalam masyarakat melalui inventarisasi konflik sumber daya alam pada masa lampau sampai sekarang, pembentukan badan nasional bertugas khusus memfasilitasi proses penyelesaian konflik, serta pembentukan badan pengadilan ad hoc yang menerima dan melanjutkan kerja badan nasional dengan mengeluarkan putusanputusan berkekuatan hukum agar pihak bersengketa mematuhinya;

b. penataan struktur penguasaan sumber daya agraria dan sumber daya alam, pemulihan ekosistem yang rusak, pembaruan peraturan perundang-undangan dengan meninjau ulang peraturan perundang-undangan sektoral dan daerah berkaitan dengan sumber daya agraria/sumber daya alam, membangun kembali payung perundangan sebagai pegangan semua peraturan sektoral dan daerah;

c. mengupayakan tercapaianya integrasi dan sinkronisasi kebijakan

\footnotetext{
${ }^{21}$ Hakim Basyar, TAP MPR RI No. IX/MPRRI/2001: Upaya Meletakkan Reformasi Kebijakan Pengelolaan Sumber Daya Alam Secara Komprehensif, diakses dari http://bappenas.go.id/index.php/download_file/vie w/10676/6845/
}

antar sektor, serta mengusahakan dengan sungguh-sungguh pembiayaan pembaharuan agraria dan pengelolaan sumber daya alam melalui perencanaan anggaran Negara.

Politik dan kebijakan pengurusan sumberdaya agraria yang tidak benarbenar menjalankan amanat konstitusi, UUPA No.5/1960 dan TAP MPR No.IX/2001 telah menempatkan penyelesaian persoalan terkait sumberdaya agaria menjadi sangat parsial dan sektoral ${ }^{22}$. Sejauh ini jika merujuk ke uraian Kementerian Agraria dan Tata Ruang/Badan Pertanahan Nasional (BPN) RI yang berjudul Sekilas Reforma Agraria, di dalamnya telah termuat maksud dan tujuan, prinsip-prinsip, arah kebijakan, dasar hukum, objek dan subjek, dari RA yang cukup komperehensif ${ }^{23}$. Di dalam uraian tersebut juga jelas-jelas dinyatakan dalam bahwa diantara tujuan dari RA di Indonesia selain mengurangi kemiskikan dan memperbaiki akses ekonomi masyarakat, juga memperbaiki dan menjaga kualitas lingkungan hidup.

Presiden Susilo Bambang Yudhoyono dalam pidato awal tahun 2007

\footnotetext{
22 Dadan Ramdan (2016), Konsep Perencanaan Pembangunan Terpadu Berbasis Reforma Agraria, http://inisiatif.org/?p=11384.

23 Baca BPN RI, Sekilas Reforma Agraria, diakses dari http://www.bpn.go.id/Program/ReformaAgraria.
} 
di TVRI (31/01/2007 malam) menyinggung tentang rencana pemerintah untuk menjalankan pembaruan agraria (RA) yang pada intinya adalah melakukan redistribusi Tanah Negara kepada sejumlah rumah tangga yang dikategorikan sebagai petani termiskin. RA ala SBY lebih ditumpukan kepada dua hal, yakni: (1) redistribusi lahan secara terbatas, dan (2) sertifikasi tanah. Sejumlah keraguan tentang RA ala Susilo Bambang Yudhoyono dijelaskan oleh Bachriadi (2007) sebagai jalan bagi pelaksanaan "Reforma Agraria Palsu”. Karena adanya kenyataan tentang pertarungan kepentingan yang berbeda di dalam tubuh rejim Susilo Bambang Yudhoyono, dan rejim ini tidak sekuat yang diduga dan diharapkan. Ada banyak kepentingan ekonomi politik para tuan tanah dan pengusaha yang terancam, sedangkan RA memerlukan suatu rejim negara kuat dan memiliki komitmen penuh untuk membela kepentingan ekonomi politik kaum tani dan rakyat miskin lainnya. Rejim lemah membuat program RA terombang-ambing dan dikooptasi oleh kepentingan lain serta potensial menyimpang dari tujuan awal ${ }^{24}$.

Komisi Nasional Hak Asasi Manusia (Komnas HAM), Wahana Lingkungan Hidup Indonesia (Walhi) dan

\footnotetext{
${ }^{24}$ Baca Dianto Bachriadi (2007), Reforma Agraria untuk Indonesia: Pandangan Kritis tentang Program Pembaruan Agraria Nasional (PPAN) atau Redistribusi Tanah ala Pemerintahan SBY.
}

Konsorsium Pembaruan Agraria (KPA) menilai, masalah konflik agraria jadi persoalan utama yang belum terselesaikan sepanjang pemerintahan Presiden Susilo Bambang Yudhoyono. Sepanjang sepuluh tahun Susilo Bambang Yudhoyono berkuasa, konflik agraria di Indonesia malah terus menunjukkan peningkatan. Telah terjadi 1.391 konflik agraria di seluruh Indonesia dengan areal konflik seluas 5 juta hektare lebih. Penyelesaian oleh Badan Pertanahan Negara (BPN) tidak dapat berjalan maksimal. Pasalnya, persoalan pertanahan yang ada sebagian disebabkan oleh pihak BPN sendiri akibat keputusan-keputusannya ${ }^{25}$.

Ketika terjadi pergantian rezim pemerintahan di Indonesia pada tahun 2014 dari kepemimpinan Susilo Bambang Yudhoyono ke Joko Widodo atau Jokowi, bagaimana dinamika pembangunan ekonomi, RA, kelestarian lingkungan berkelanjutan, dan konflik sosial atas tanah? Pemerintahan Presiden Jokowi dan Wapres Jusuf Kalla (JK) berlangsung sejak 20 Oktober 2014 menghidupkan kembali Kementerian Agraria. Kementerian yang mengurusi pertanahan ini pertama kali dibentuk pada era Presiden Soekarno dalam Kabinet Sukiman-Suwiryo pada

\footnotetext{
${ }^{25}$ Lebih dari 1.000 Konflik Agraria Terjadi di Era Presiden SBY, 10/09/2014, http://indonesia.ucanews.com/2014/09/10/lebihdari-1-000-konflik-agraria-terjadi-di-era-presidensby/
} 
tahun 1951. Sejak Kabinet Dwikora II tahun 1966 hingga pemerintahan berganti dipegang oleh Presiden Soeharto dari Kabinet Pembangunan I hingga Kabinet Pembangunan V, Kementerian Agraria ditiadakan. Pada Kabinet Pembangunan VI tahun 1993, Presiden Soeharto membentuk Kementerian Negara Agraria/Kepala Badan Pertanahan Nasional (BPN). Kementerian itu terus ada hingga pemerintahan Presiden BJ Habibie. Pada era pemerintahan Presiden Abdurrahman Wahid 1999-2001, Kementerian Negara Agraria dibubarkan melalui Keputusan Presiden Nomor 154 Tahun 1999 sedangkan jabatan Kepala BPN dirangkap oleh Menteri Dalam Negeri. Pelaksanaan pengelolaan pertanahan dilaksanakan oleh Wakil Kepala BPN. Pada era pemerintahan Presiden Megawati Soekarnoputri 20012004 hingga berakhirnya pemerintahan Presiden Susilo Bambang Yudhoyono 2014-1014, Kementerian Agraria juga ditiadakan ${ }^{26}$.

Pada 7 April 2016 Pemerintah Indonesia melalui Kementerian Agraria dan Tata Ruang mengeluarkan Peraturan Menteri ATR No. 18 Tahun 2016. Pasal 3 menetapkan pembatasan kepemilikan tanah pertanian untuk perorangan, 20

\footnotetext{
${ }^{26} 2$ Tahun Pemerintahan Jokowi-JK, Dua Tahun Jokowi-JK Hidupkan Reforma Agraria, Kamis, 20 Oktober 2016 16:33, http://elshinta.com/news/83849/2016/10/20/duatahun-jokowi-jk-hidupkan-reforma-agraria.
}

hektar maksimum untuk daerah tidak padat dan 12 hektar maksimum untuk daerah kurang padat. Diperkuat dengan kewajiban bahwa tanah hanya dapat dialihkan kepada pihak lain yang berdomisili di dalam 1 kecamatan dan harus dipergunakan untuk pertanian. Pada 14-18 April 2016, dilaksanakan Multilateral Meeting di Bappenas, menghasilkan program "Prioritas Nasional Reforma Agraria” dalam hal kedaulatan pangan, yaitu (1) Penguatan Kerangka Regulasi dan Penyelesaian Konflik Agraria, dilakukan pengkajian atas peraturan perundangundangan pendukung RA, terhadap kasuskasus konflik agraria, menyusun pendapat dan rekomendasi konflik agraria, pengkajian hak, pengawasan lembaga dalam menjalankan rekomendasi tersebut, dan mediasi. (2) Penataan Penguasaan dan Pemilikan Tanah Obyek Reforma Agraria (TORA), dilakukan identifikasi dahulu terhadap tanah-tanah yang menjadi obyek, seperti Kawasan Hutan yang akan Dilepaskan, tanah terlantar, dan juga mengidentifikasi subyek penerima manfaat RA. (3) Kepastian Hukum dan Legalisasi Hak atas TORA, dilakukan perbaikan petugas pemetaan dan petugas RA di Kabupaten/Kota, meningkatkan cakupan peta dasar pertanahan, meningkatkan cakupan bidang tanah bersertifikat untuk rakyat miskin melalui legalisasi aset, publikasi tata batas hutan, legalisasi tanah 
transmigrasi, dan sosialisasi tanah ulayat.

(4) Pemberdayaan Masyarakat dalam Penggunaan, Pemanfaatan, dan Produksi atas TORA, dilakukan koordinasi lokasi dan target pemberdayaan TORA, penyediaan teknologi dan fasilitas produksi pertanian, peternakan, perkebunan, dan bantuan modal serta fasilitas.

Pengalokasian Sumber Daya Hutan untuk Dikelola Rakyat, dilakukan pendataan dan pemetaan alokasi sumber daya hutan, menetapkan alokasi pemanfaatan hutan oleh rakyat, memberdayakan masyarakat untuk mengelola hutan, menyediakan lembaga dan biaya pelaksanaan, dan menguatkan hak dan akses pengusaan hutan kepada masyarakat.

Kelembagaan Pelaksana Reforma Agraria Pusat dan Daerah, dibentuk pedoman teknis dan gugus tugas pelaksana di pusat dan daerah. Kemudian perpres lembaga penyediaan tanah bagi pembangunan kepentingan umum disusun besera dengan prioritas penyediaan tanah ${ }^{27}$.

Sasaran RA selama tahun 20142016, dijalankan Kementerian Agraria dan Tata Ruang/BPN adalah program reistribusi dan legalisasi yang berlangsung sampai dengan 31 Agustus 2016.

\footnotetext{
${ }^{27}$ Howard J. Tigris (2016), Kebijakan Dan Pelaksanaan Landreform Di Era Pemerintahan Jokowi-JK,

http://rechtsvinding.bphn.go.id/jurnal_online/2016. 11.04-

KEBIJAKAN\%20DAN\%20PELAKSANAAN\%20 LANDREFORM\%20\%20DI\%20ERA\%20PEMER INTAHAN\%20JOKOWI-JK.pdf.
}

Legalisasi diselenggarakan atas tanahtanah yang sebelumnya dijadikan tanah obyek RA dan tanah rakyat miskin lainnya. Pada 2015, realisasi legalisasi aset mencapai 836.921 bidang tanah atau 188.307 hektare. Pada tahun 2016 ditargetkan legalisasi aset mencapai 1.050.073 bidang tanah atau 236.266 hektare. Sementara redistribusi tanah dilakukan pada tanah-tanah HGU (hak guna usaha) yang habis masa berlakunya, tanah terlantar, dan tanah negara lainnya. Tahun 2015, redistribusi tanah telah mencapai 90.829 bidang tanah atau 63.985 hektare. Tahun 2016 telah mencapai 175 ribu bidang tanah atau 123.280 hektare. Pemerintah telah mengidentifikasi tanah terlantar. Pada tahun 2015, dari 119 yang ditargetkan, telah terealisasi 91 tanah terlantar yang dapat diidentifikasi. Pada tahun 2016, baru terealisasi 66 dari target 205 bidang tanah yang diidentifikasi terlantar. Pada 2015, pemerintah dapat menyelesaikan 515 kasus dari 932 kasus sengketa dan konflik agraria, sedangkan pada tahun 2016 baru 251 kasus selesai dari 2.642 kasus sengketa dan konflik agraria. Sebagai upaya mengakselerasi capaian dari pelaksanaan RA, Presiden Jokowi pada 14 Mei lalu menerbitkan Peraturan Presiden Nomor 45 Tahun 2016 tentang Rencana Kerja Pemerintah 2017 yang didalamnya menempatkan RA sebagai prioritas nasional. Prioritas 
nasional dalam RA mencakup penguatan kerangka regulasi dan penyelesaian konflik, kelembagaan pelaksana reforma agraria pusat dan daerah, penataan penguasaan dan pemilikan tanah obyek reforma agraria (TORA), pemberdayaan masyarakat dalam pemanfaatan TORA, dan kepastian hukum dan legalisasi atas TORA. Rapat kabinet terbatas tentang reforma agraria pada 24 Agustus 2016, Presiden Jokowi telah memerintahan untuk segera mempercepat program reforma agraria ini $^{28}$.

Sejak 2013, pembangunan infrastruktur kerap jadi biang kerok konflik lahan. Konsorsium Pembaruan Agraria (KPA) mencatat ada 105 konflik agraria yang disebabkan proyek infrastruktur. Tahun 2014, angkanya melonjak dua kali lipat lebih, menyentuh 215. Tahun 2015, konflik lahan pada proyek infrastruktur turun menjadi hanya 70 kasus. Ini karena tahun 2014 adalah puncak pembebasan lahan dari program MP3EI. Akar konflik agrarian kekinian di Indonesia adalah pemberlakuan Undang-undang No. 2/2012 tentang Pengadaan Tanah Bagi Pembangunan untuk Kepentingan Umum dan produk hukum turunannya. Sejak adanya beleid ini, perampasan tanah rakyat

\footnotetext{
${ }^{28} 2$ Tahun Pemerintahan Jokowi-JK, Dua Tahun Jokowi-JK Hidupkan Reforma Agraria, Kamis, 20 Oktober 2016 16:33, http://elshinta.com/news/83849/2016/10/20/duatahun-jokowi-jk-hidupkan-reforma-agraria.
}

atas nama pembangunan menjadi begitu mudah $^{29}$.

Sepanjang tahun 2015, KPA mencatat sedikitnya telah terjadi 252 kejadian konflik agraria di tanah-air, dengan luasan wilayah konflik mencapai 400.430 hektar. Konflik-konflik ini melibatkan sedikitnya 108.714 kepala keluarga (KK). Jika di tahun sebelumnya (2014), sektor pembangunan infrastruktur menjadi penyebab tertinggi konflik agraria, maka di tahun 2015 ini, konflik agraria paling banyak terjadi di sektor perkebunan yakni sebanyak 127 konflik (50\%). Selanjutnya konflik di sektor pembangunan infrastruktur menempati posisi kedua terbanyak sebanyak 70 konflik (28\%), lalu di sektor kehutanan 24 konflik (9,60\%), sektor pertambangan 14 (5,2\%), kemudian lain-lain 9 konflik (4\%), dan di sektor pertanian dan sektor pesisir/kelautan di urutan kelima masingmasing sebanyak 4 konflik $(2 \%)^{30}$.

Di sektor lingkungan hidup, ada empat indikator yang membuat Jokowi dianggap tidak berpihak kepada pembangunan berkelanjutan. Pertama, menggabungkan

Kementerian

Lingkungan Hidup (KLH) dengan

Kementerian

Kehutanan

(Kemenhut). Kedua, Jokowi dan kabinet

\footnotetext{
${ }^{29}$ Proyek Infrastruktur Jokowi Jadi Biang Konflik Agraria, https://tirto.id/proyek-infrastrukturjokowi-jadi-biang-konflik-agraria-b5yx. ${ }^{30}$ http://www.kpa.or.id/news/publikasi/.
} 
kerja bicara poros maritim, kesan yang ditangkap adalah eksploitasi laut besarbesaran, tidak pernah bicara keprihatinan kondisi terumbu karang dan hutan manggrove yang sangat kritis. Bekerja mengelola laut harus berangkat dari kondisi riil laut. Berbicara pencurian ikan tanpa bicara kondisi peralatan nelayan sehingga tidak mampu menangkap ikan di laut lepas. Ketiga, hilangnya institusi yang berfungsi pengawasan pembangunan secara fisik. Keempat, Diterbitkannya Peraturan Menteri (Permen) Lingkungan Hidup dan Kehutanan Nomor 97 tahun 2014 tentang pendelegasian wewenang pemberian perizinan dan non perizinan di bidang lingkungan hidup dan kehutanan dalam rangka pelaksanaan pelayanan terpadu satu pintu kepada Badan Koordinasi Penanaman Modal (BKPM). Kebijakan ini menunjukkan bahwa pemerintahan Jokowi mengutamakan pertumbuhan ekonomi dan mengenyampingkan lingkungan $^{31}$. Selain itu, perlu untut dicatat bahwa tahun 2015 adalah periode terburuk dan paling lama dari bencana kabut di Indonesia. Krisis asap yang diciptakan oleh kebakaran hutan di Indonesia merupakan kejadian tahunan, akan tetapi tahun 2015 menjadi sangat

\footnotetext{
${ }^{31}$ Gurgur Manurung, Eksploitasi Lingkungan Era Jokowi, Sabtu, 13 Juni 2015, http://harian.analisadaily.com/lingkungan/news/eks ploitasi-lingkungan-era-jokowi/142506/2015/06/14.
}

buruk bahkan terparah sepanjang sejarah dengan Indonesia sendiri melaporkan korban tewas 19 orang dan setengah juta jiwa warga menderita penyakit pernafasan. Sebanyak 23 perusahaan yang bertanggung jawab atas kebakaran hutan dinyatakan di denda dan yang memiliki izin pembukaan lahan dicabut oleh Pemerintah Indonesia. Indonesia bukanlah satu-satunya negara yang terkena dampak kabut asap. Banyak negara tetangga yang juga ikut merasakan dampak dari kabut asap tersebut ${ }^{32}$.

Pemerintah Indonesia telah berkomitmen memperhatikan aspek lingkungan dalam gerak pembangunan. Antara lain, janji pembenahan tata kelola lingkungan seperti hutan dan lahan, sampai penegakan hukum bagi pelanggar aturan. Selama 2016, mulai ada upaya baik dan perkembangan positif, tetapi tak dipungkiri masih banyak catatan kelam. Kalangan organisasi masyarakat sipil masih melihat, pemerintah lebih berpihak proyek pembangunan, minim perhatian perlindungan fungsi lingkungan dan hak masyarakat atas lingkungan baik dan sehat. Penegakan hukum lingkungan dan sumber daya alam belum berjalan transparan, akuntabel dan sinergis antarinstitusi ${ }^{33}$.

\footnotetext{
3215 Masalah Lingkungan Hidup Dunia Yang Terparah Sepanjang Tahun 2015, http://www.limbahb3.com/15-masalah-lingkunganterparah-pada-tahun-2015/

33 Della Syahni dan Sapariah Saturi (2017), Bercermin 2016, Benahi Kelola Lingkungan Tahun Ini,
} 


\section{Kesimpulan}

Dari pemaparan di atas, dapat diketahui bahwa pembangunan berkelanjutan di Indonesia kekinian belum berhasil dengan baik diselenggarakan jika dihubungkan antara kebutuhan untuk Reforma Agraria, peningkatan kesejahteraan ekonomi, pelestarian lingkungan berkelanjutan, dan meredam konflik sosial akibat tanah dan sumber daya alam lainnya. 